

\section{The Together Project:}

\section{Thabarwa Meditation Center}

\section{Johanna Patton}

Keywords: Community, Meditation Center, Asia, Myanmar, Buddhism, Humanity, Documentary Photography

\section{Abstract}

The Together Project is a series of photo essays inspiring us to see humankind in a different light by simultaneously honoring our differences and highlighting that we are so much more alike than we think we are. The Together Project is here to inspire you to have meaningful conversations, connect with others, to live life curiously, and to believe in one another.

In this photo essay, Johanna explores Thabarwa Meditation Center located in Thanlyin, Myanmar and shares her experience as well as the customs that take place there. 


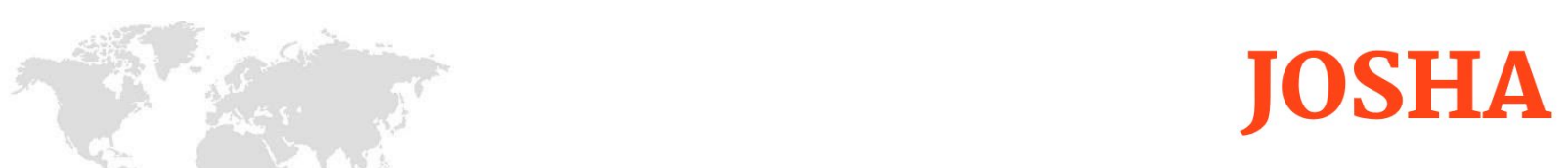

Journal of Science, Humanities and Arts

January 2021

Volume 8 , Issue 1

\section{The Together Project}

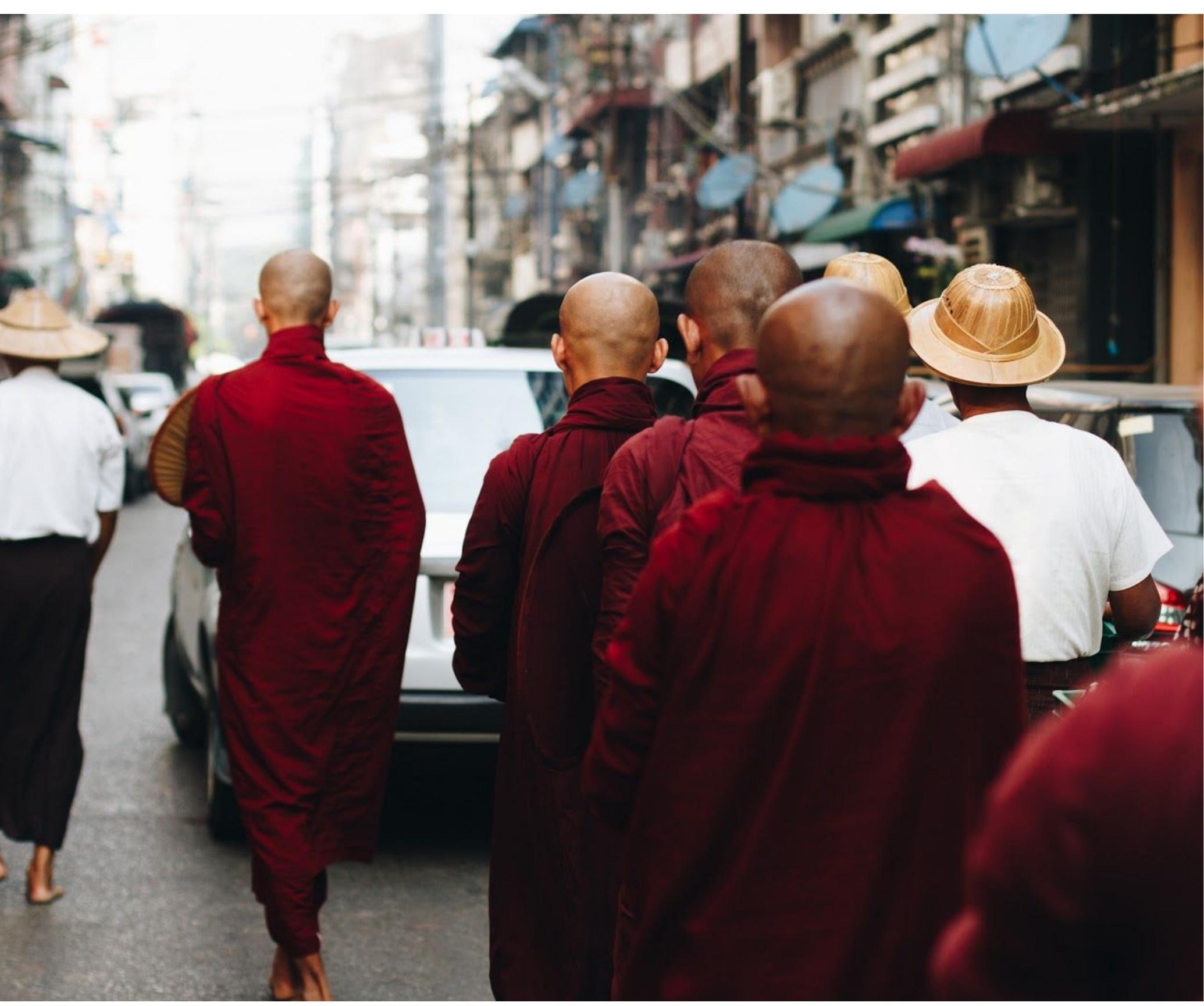




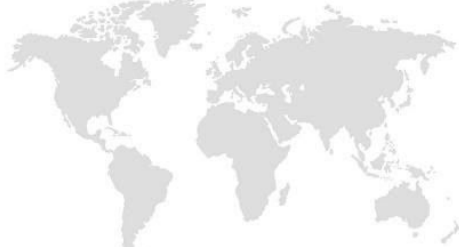

\section{JOSHA}

Journal of Science, Humanities and Arts

Volume 8 , Issue 1

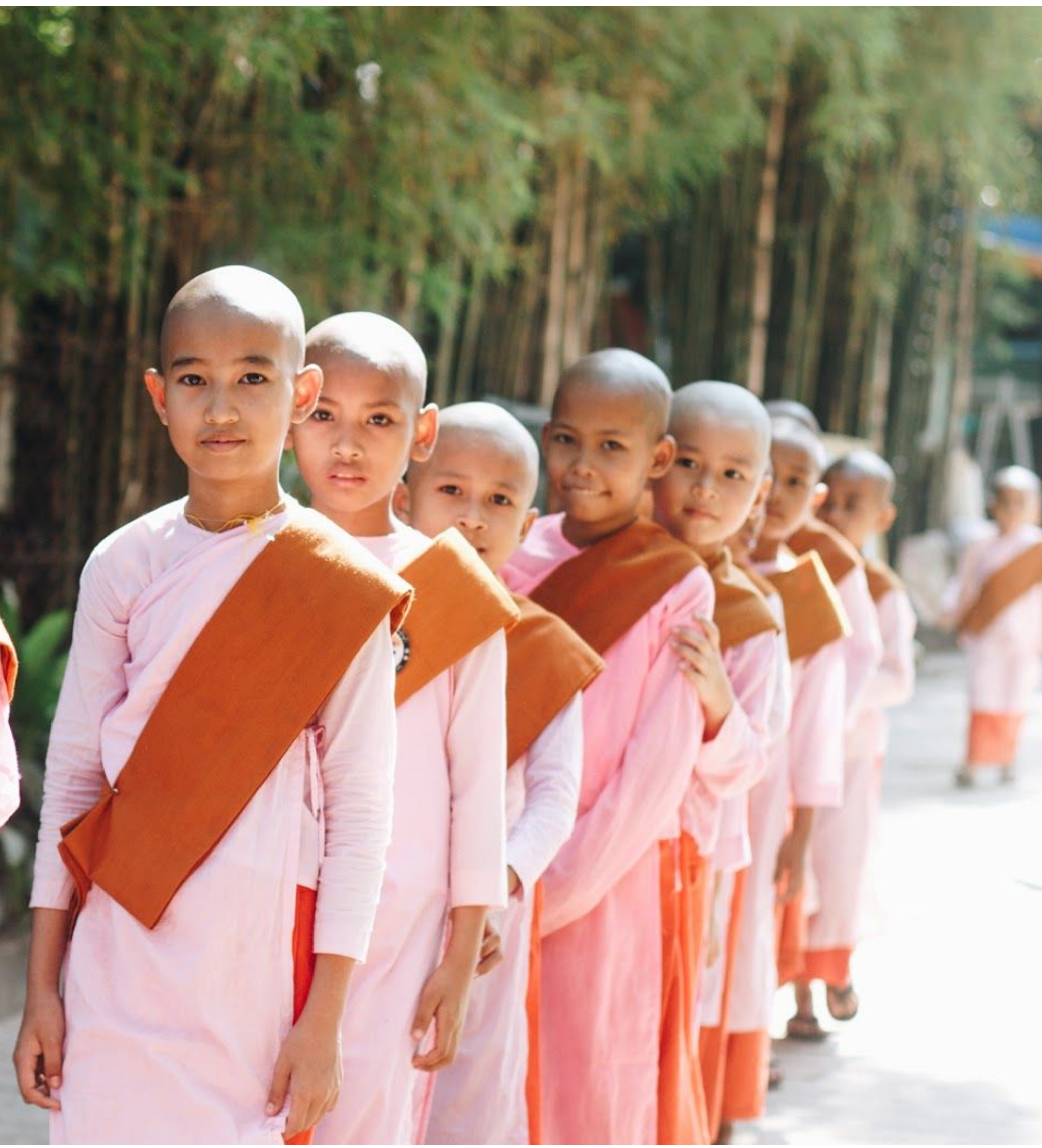


Journal of Science, Humanities and Arts

\section{A HOME}

\section{FOR ALL}

Thabarwa Meditation Center was founded by the monk Sayadaw Ottamathara in 2008 in Thanlyin, Myanmar. The center was created with the intent of giving the old, sick, and homeless a place of peace where they could find accommodation, food, education, and the opportunity to meditate. It's a place people come to live and to die- a place where they can meditate peacefully and happily, do good deeds, and to

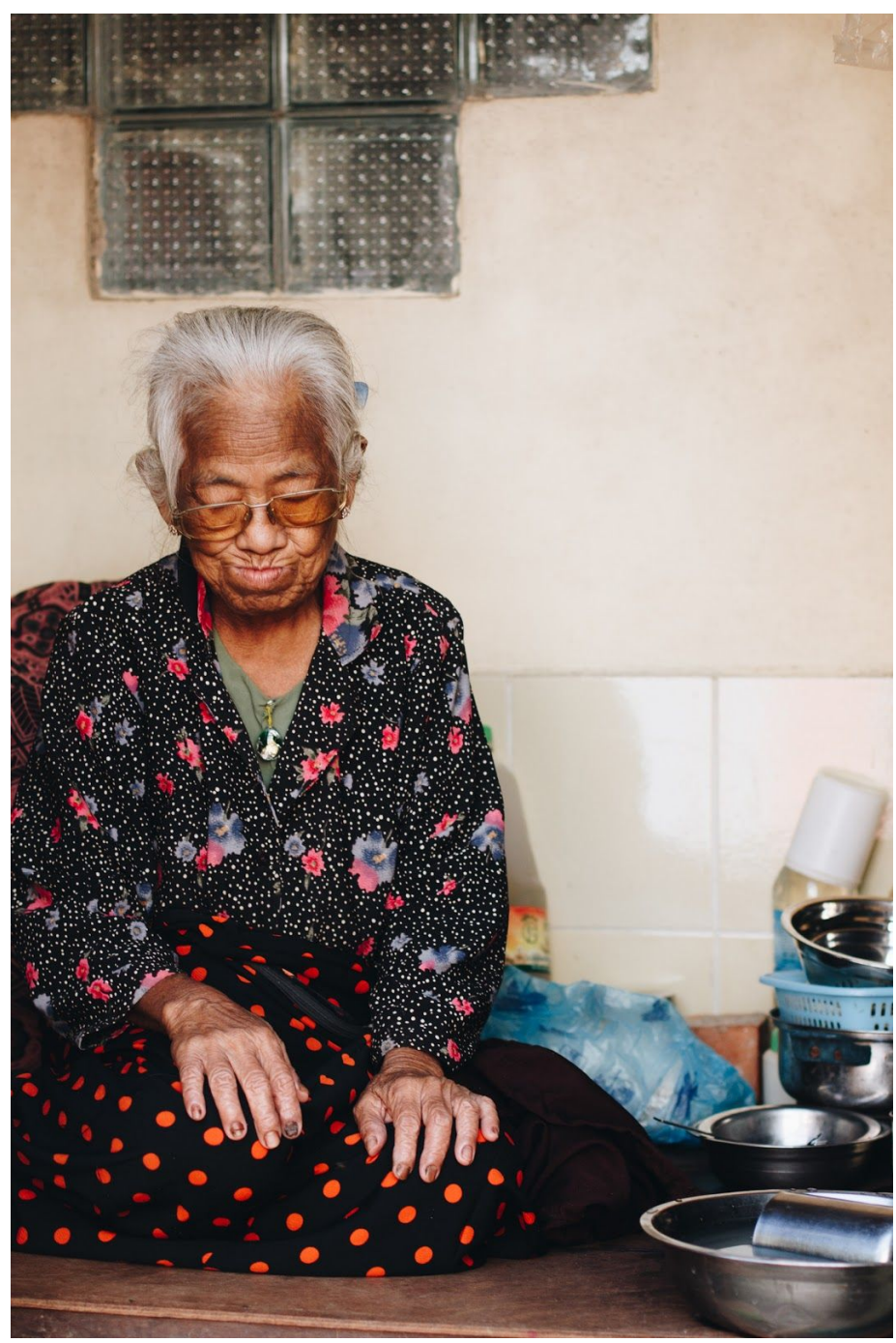
find a deep sense of community.

Despite their situation, they can find peace in this center. It's truly a home for all. One may think a meditation center looks and feels a certain way. Often we think it's a small, quiet place where a few monks live to practice meditation. Although monks live here and meditation is practiced, it is probably much different than what most people imagine. Thabarwa is a large village that accommodates more than 3,400 people running completely on donations. Volunteers come from across the globe hoping to help out in any way they can whether that be giving English lessons, washing patients, physiotherapy sessions, or taking patients on wheelchairs to the nearby Pagodas. 


\section{JOSHA}

Journal of Science, Humanities and Arts

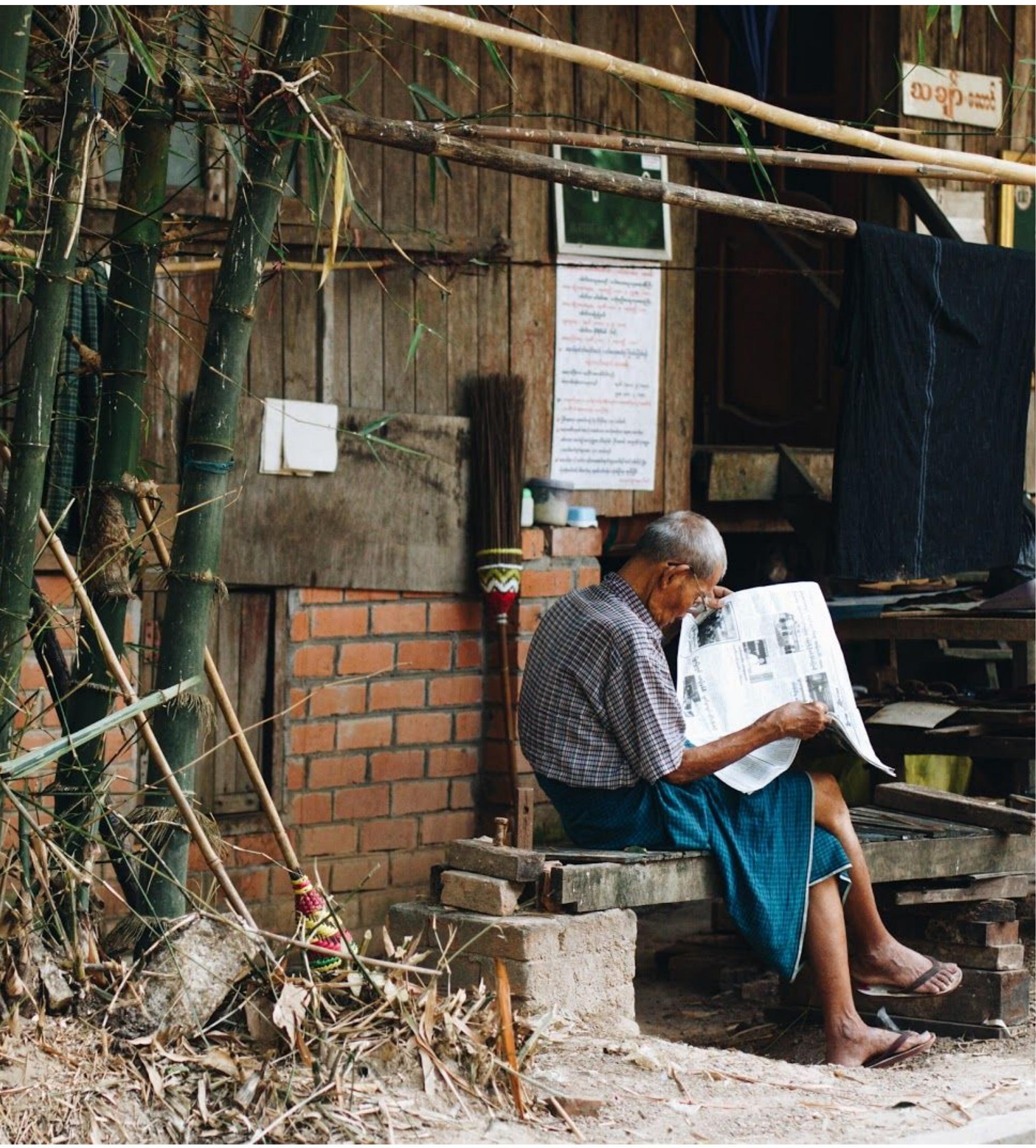
Whis 


\section{JOSHA}

Journal of Science, Humanities and Arts

January 2021

Volume 8, Issue 1

\section{ALMS}

In the morning, monks walk through different nearby villages and cities collecting alms. Alms rounds consist of monks walking barefoot through said villages or cities while a man or woman calls out a signal to let the residents know the monks are passing by. They walk out of their homes with cooked food for the monks to collect and bring back to the center. In return, those who give food to the monks receive a blessing.

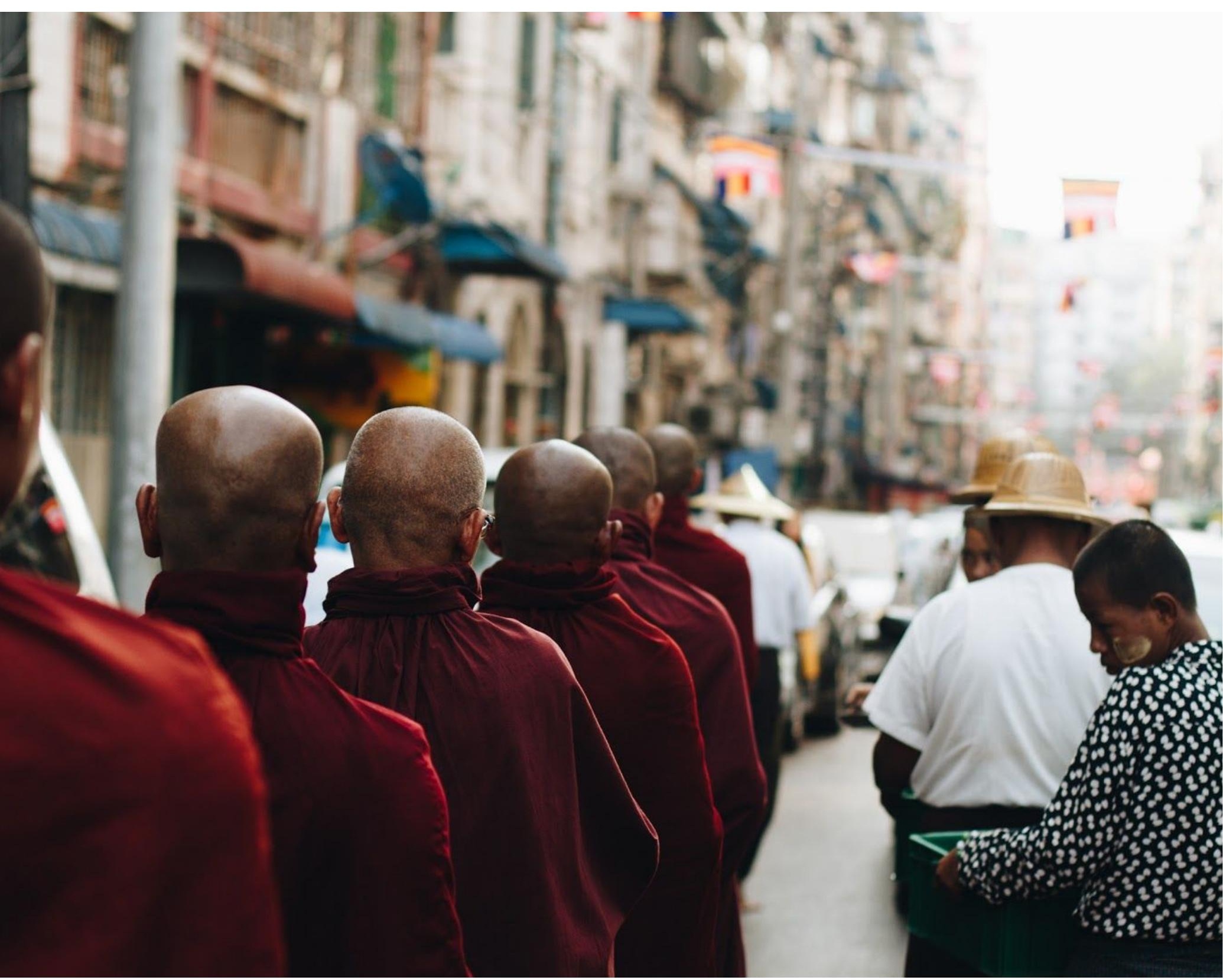




\section{JOSHA}

Journal of Science, Humanities and Arts
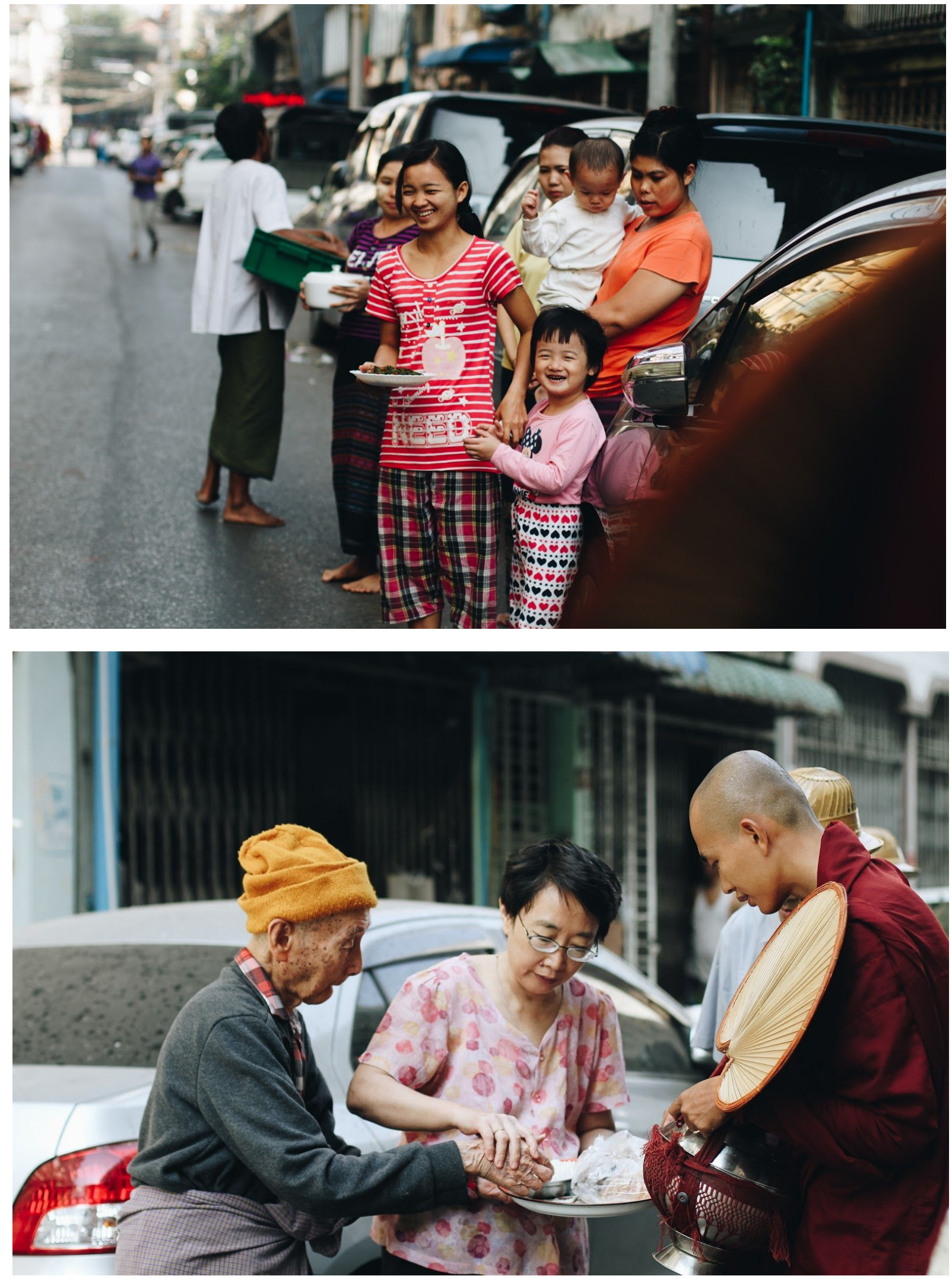


\section{JOSHA}

Journal of Science, Humanities and Arts
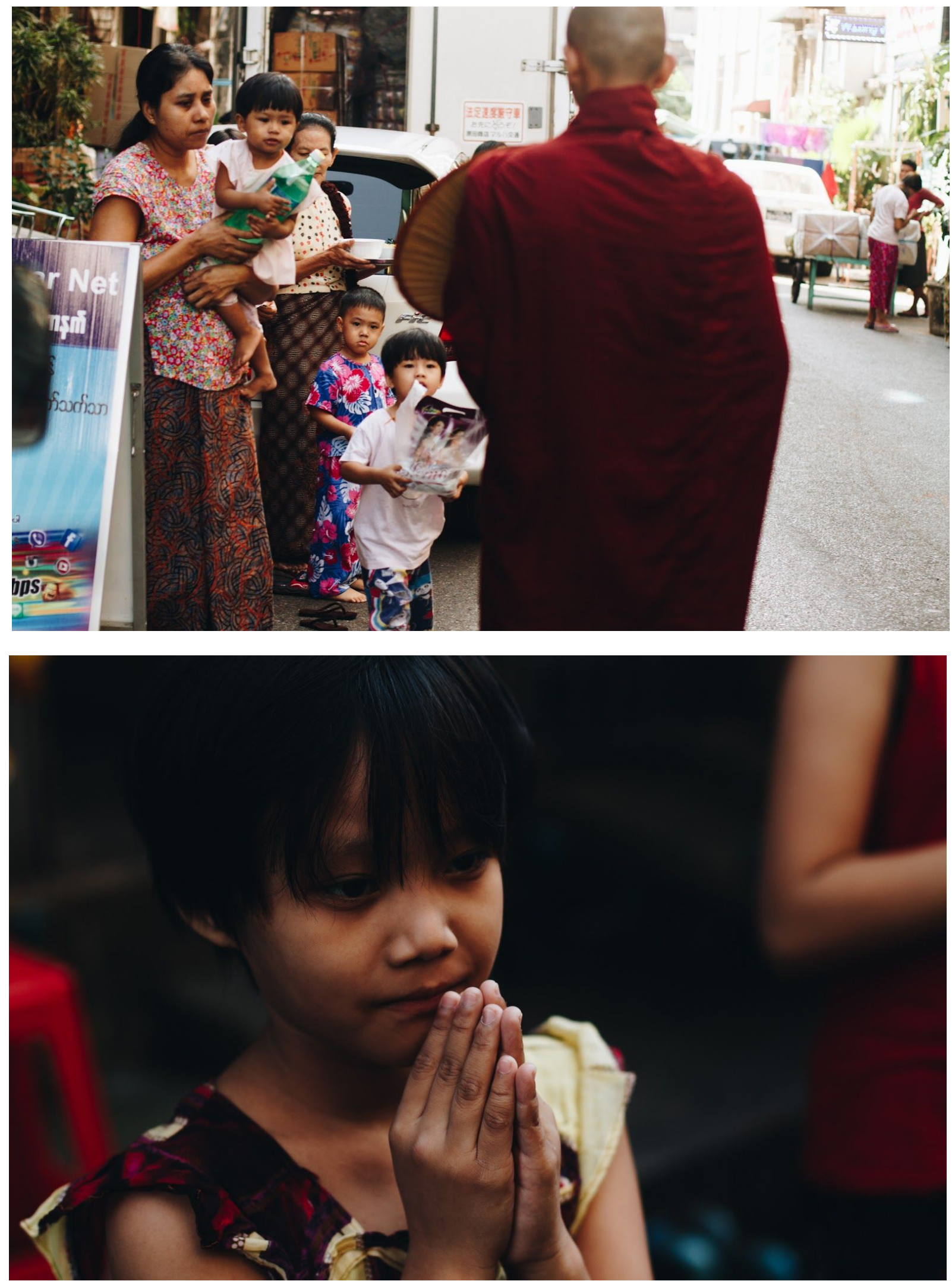


\section{JOSHA}

Journal of Science, Humanities and Arts

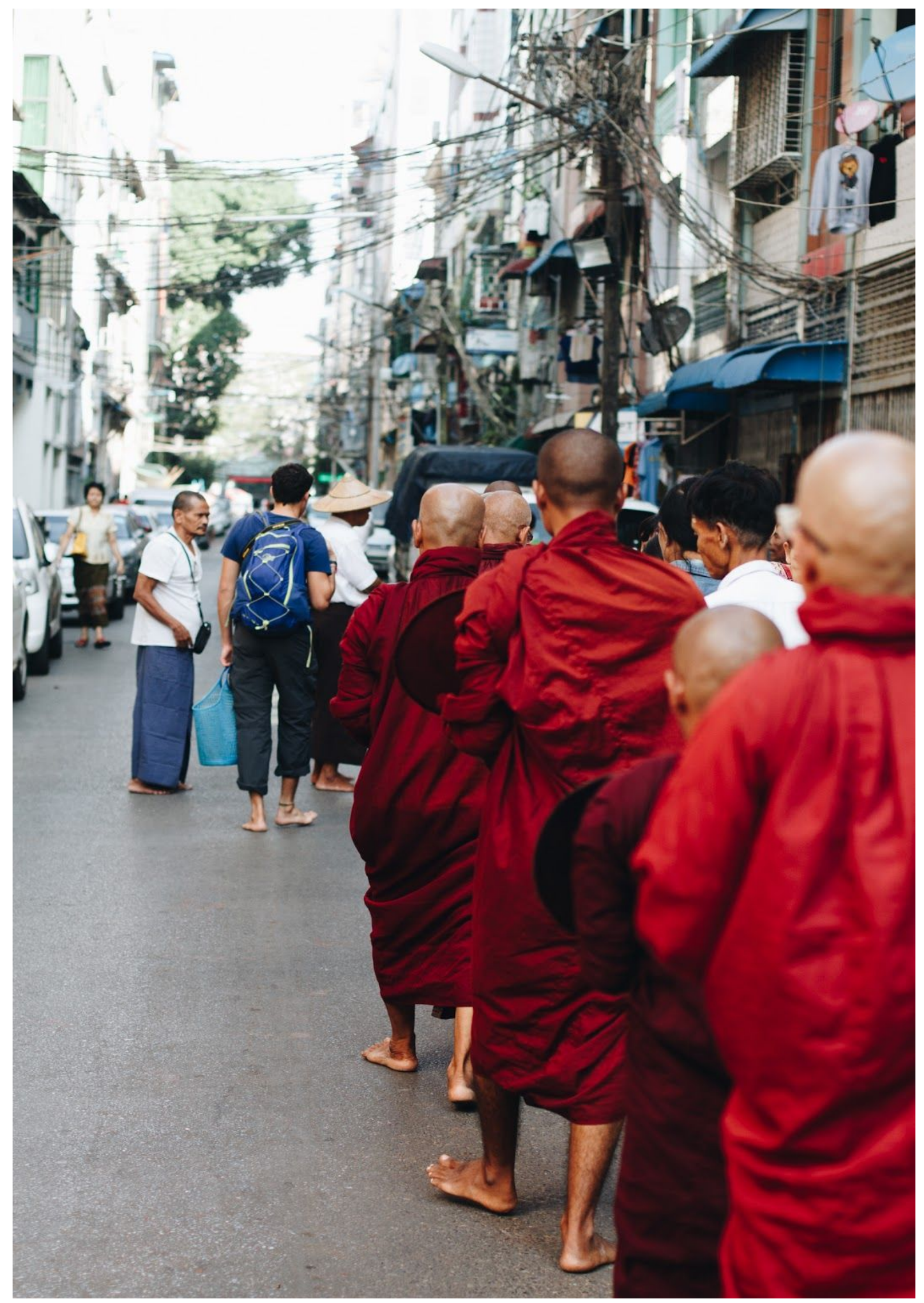




\section{JOSHA}

Journal of Science, Humanities and Arts

Volume 8 , Issue 1

\section{GOOD DEEDS}

The entire premise of coming here is to do good deeds. When you can help or lend a hand, you do so. In return, the help is reciprocated as well. The whole idea is living as a community and to take care of one another. I too had the intent of helping once I got to the center, but it was soon clear that what I received from this community was unfathomably higher than what I could ever give. The patients who lived here brought so much clarity to me about what it meant to be a part of something bigger than yourself. There was a tremendous amount of joy that came from being a part of this center and ultimately changed the way I wanted to live from that moment forth.

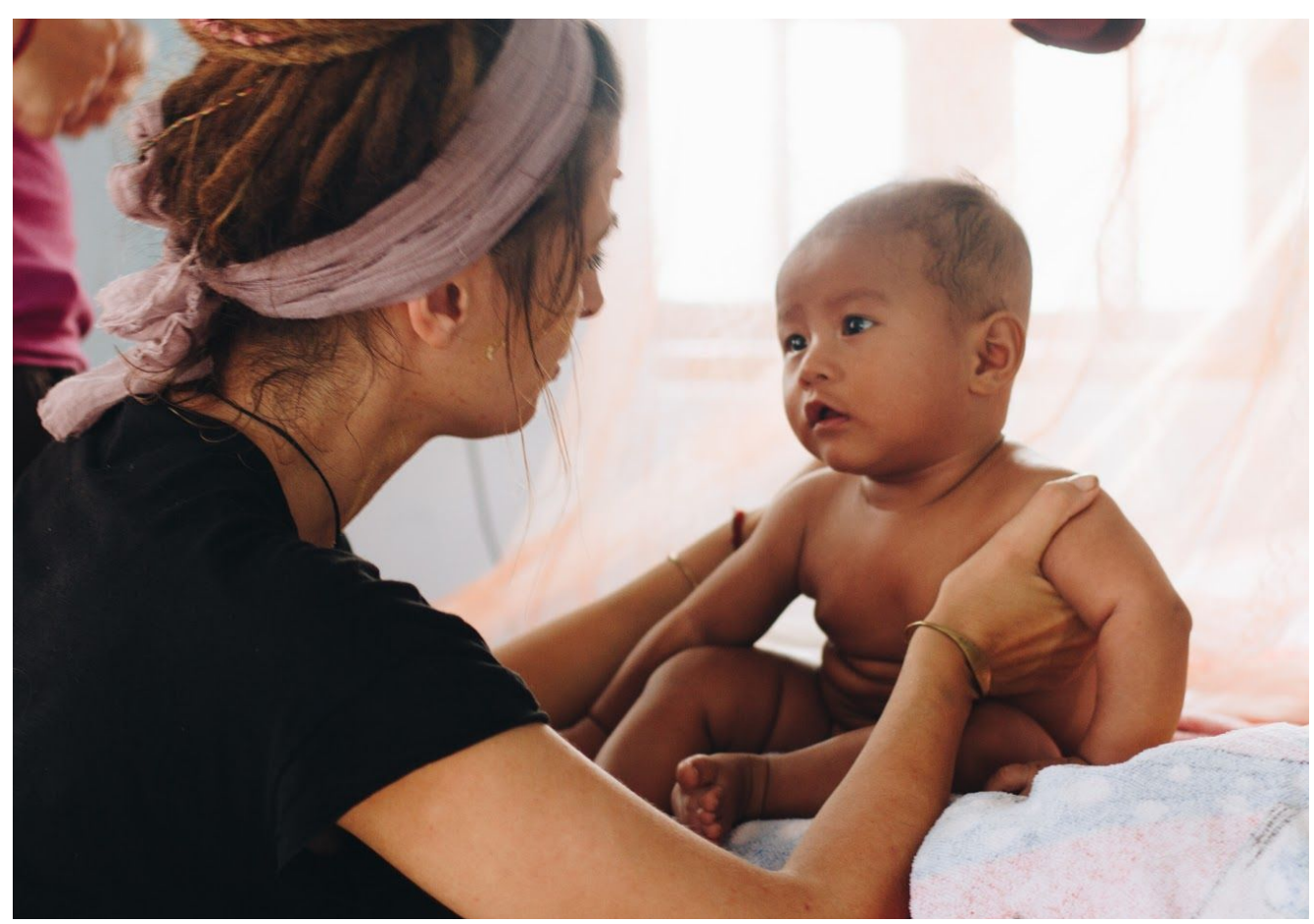




\section{JOSHA}

Journal of Science, Humanities and Arts
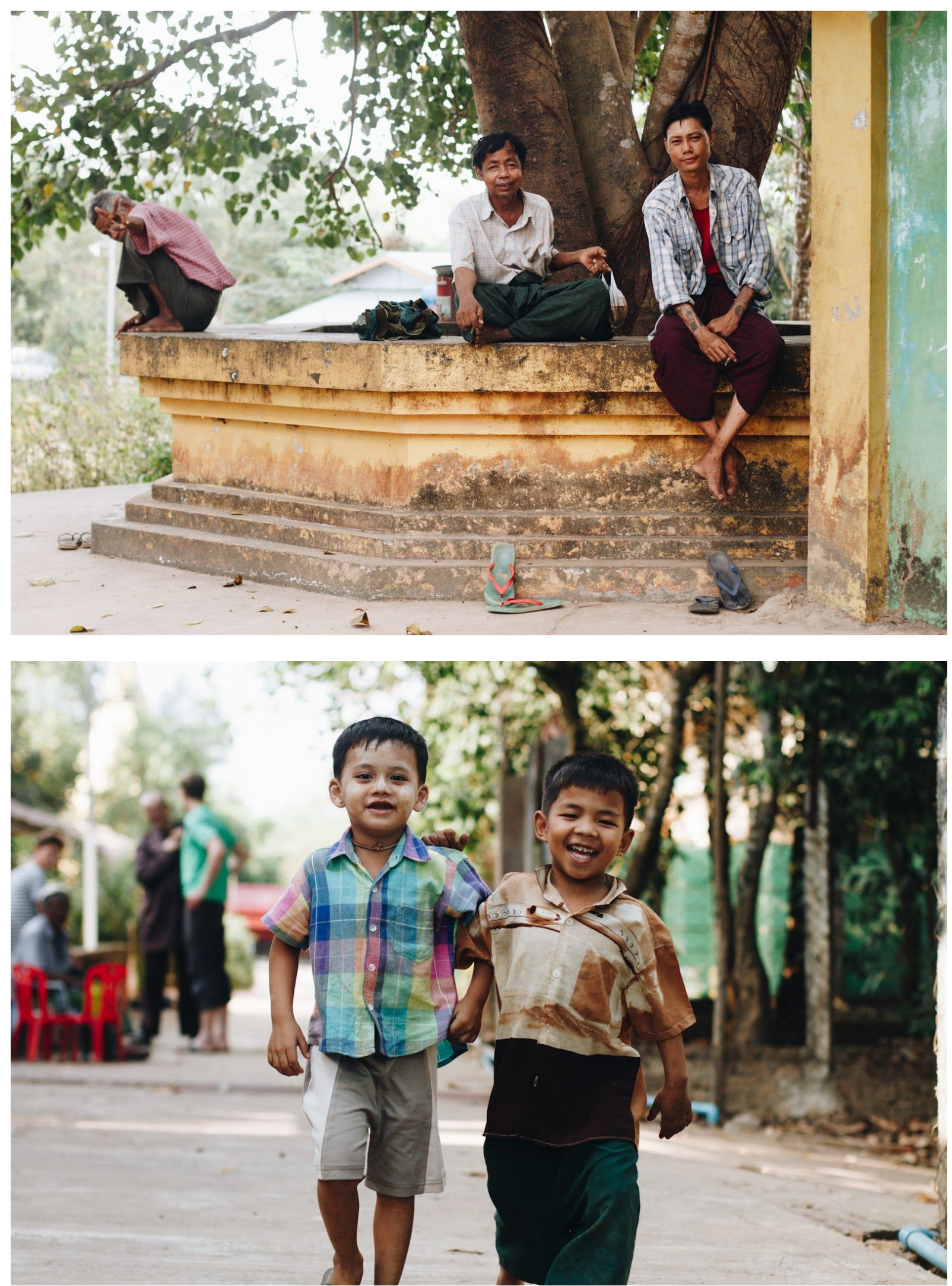


\section{JOSHA}

Journal of Science, Humanities and Arts

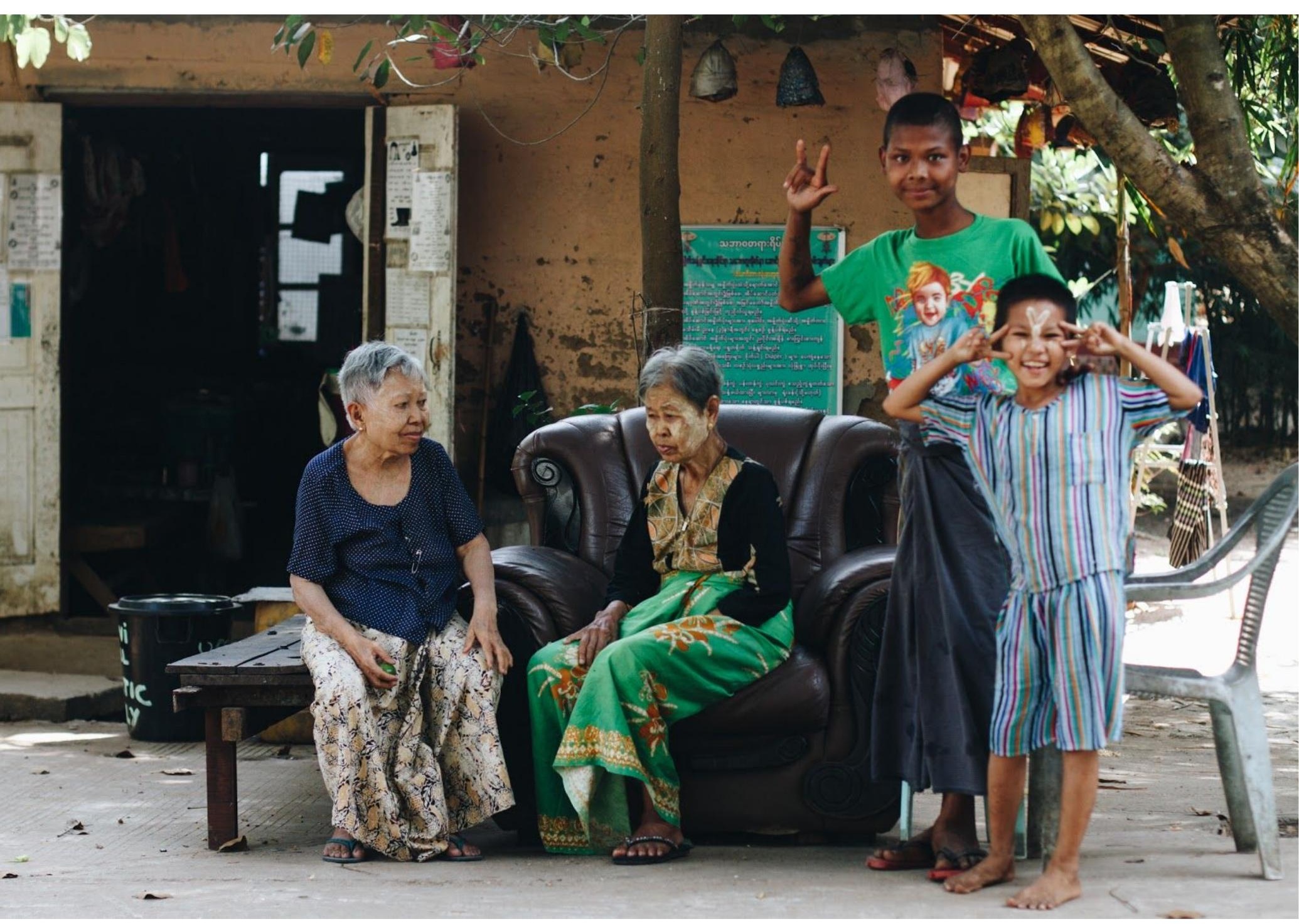

Thabarwa is such a difficult place to explain because it is a place that must be felt and seen with your own eyes. When you come from the west you can take a look and automatically assume how little these people have. In the material sense that is undeniably true. Although that may be true, material possessions doesn't mean someone is "poor." I saw a wealth of love, connection, and community I had never seen in my life back in the west. The amount of love I saw in this community had me questioning what we're trying to strive for in western society. What are we trying to fulfill by trying to climb up the ladder of success when we're bringing so much anxiety and restlessness in our lives by doing so? 


\section{JOSHA}

Journal of Science, Humanities and Arts

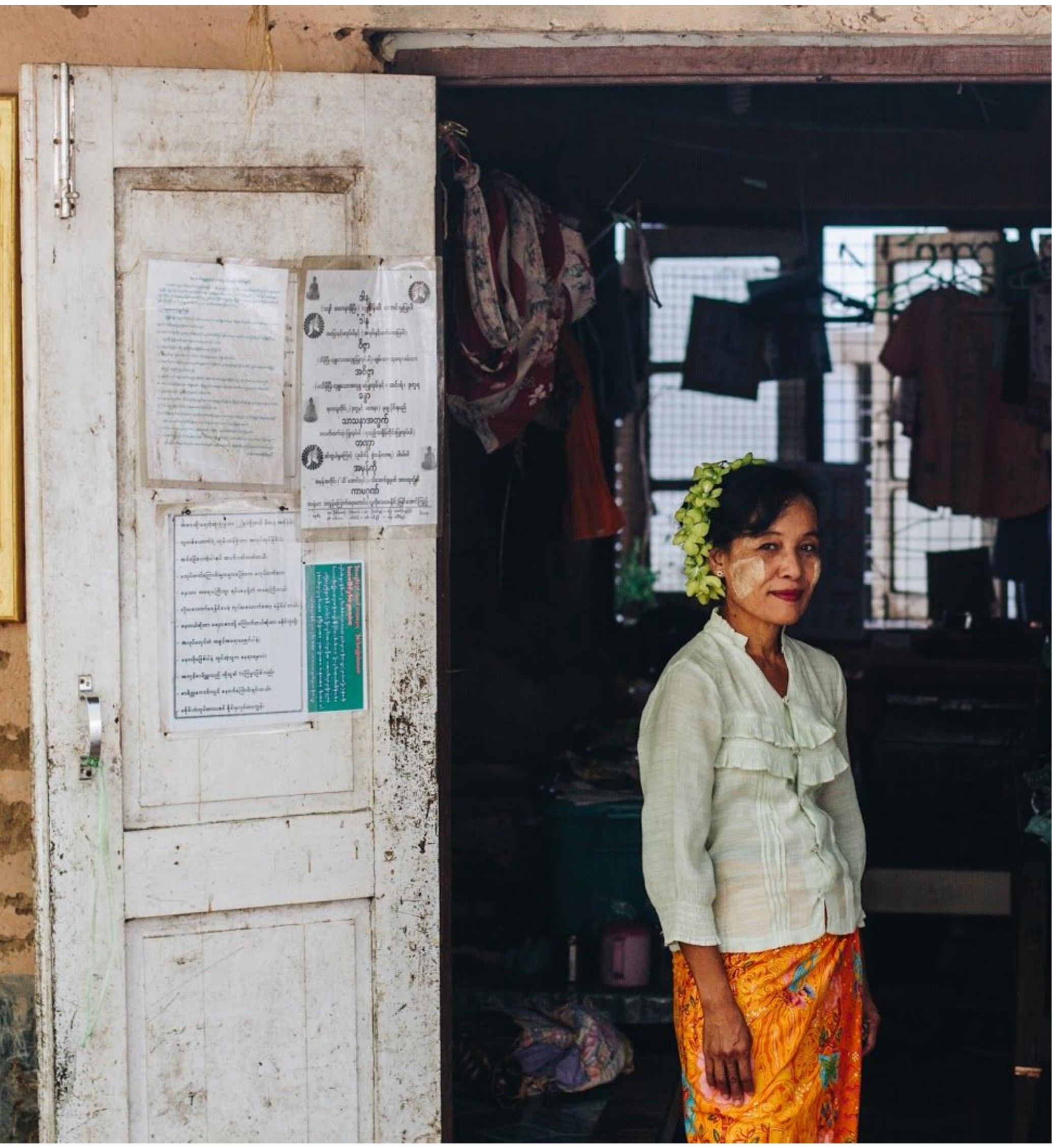




\section{JOSHA}

Journal of Science, Humanities and Arts

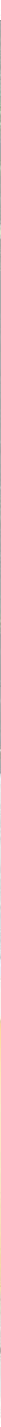

\section{BUDDHIST INFLUENCE}

The ideals they teach through Buddhism encompass non-attachment, silencing the mind, and doing good for others. A patient who lived across the street from the building where the volunteers slept at night was nicknamed the "Tea Man." He was physically disabled and owned only a couple of plastic cups, a few broken chairs, and some tea leaves. The magic of the Tea Man is that he didn't present himself with what he didn't have- in fact, it was just the opposite. He made tea his way of community building. He would wake up early in the morning and do his 5:00am meditation and shortly after walk to get hot water so he could make piping hot tea and invite passersby to sit with him. Although the Tea Man didn't speak much 


\section{JOSHA}

Journal of Science, Humanities and Arts

English, he did know a few words which I heard him speak every day. Those words were: "I am happy."

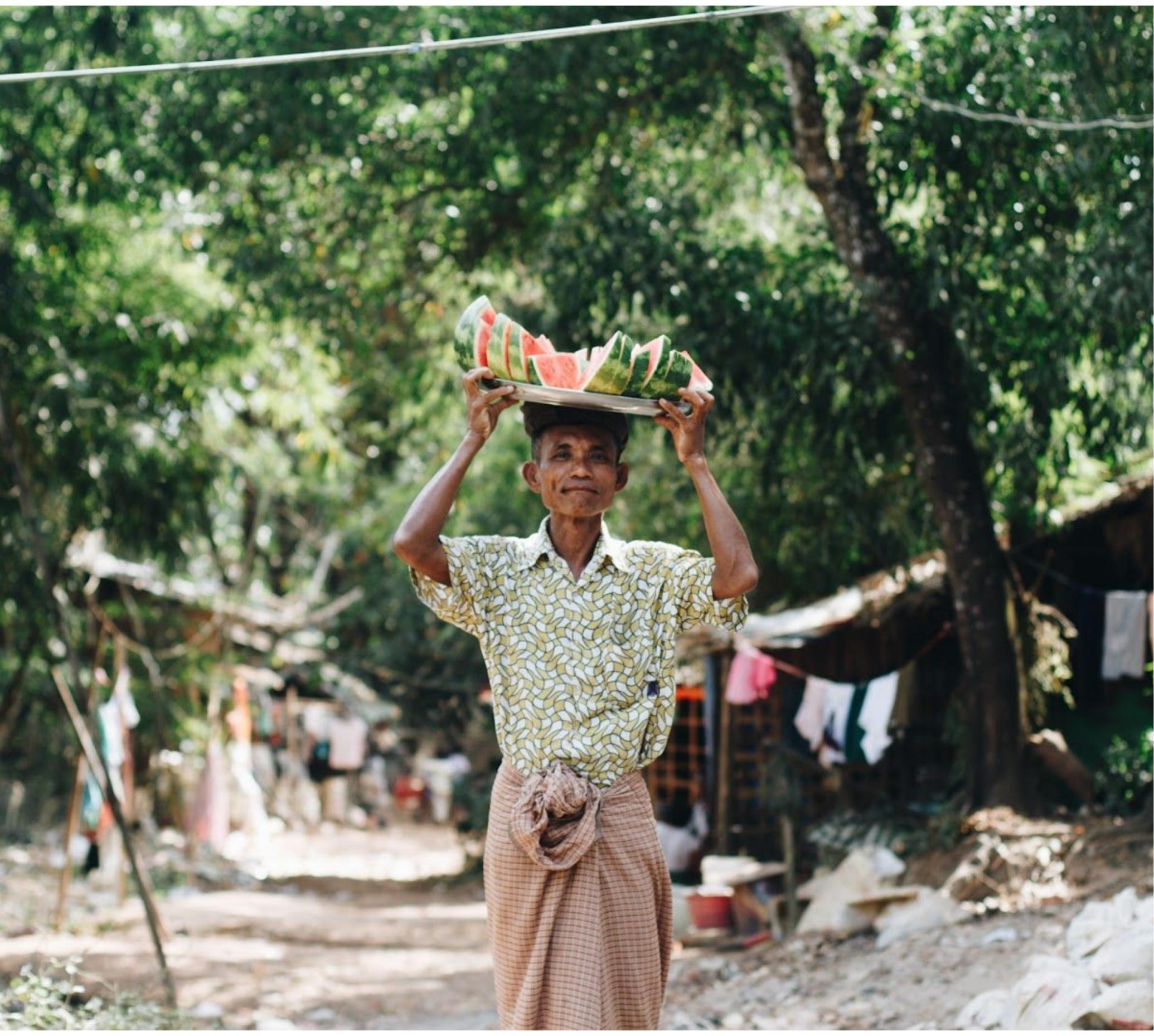


JOSHA

Journal of Science, Humanities and Arts

January 2021

Volume 8 , Issue 1

\section{About the Author:}

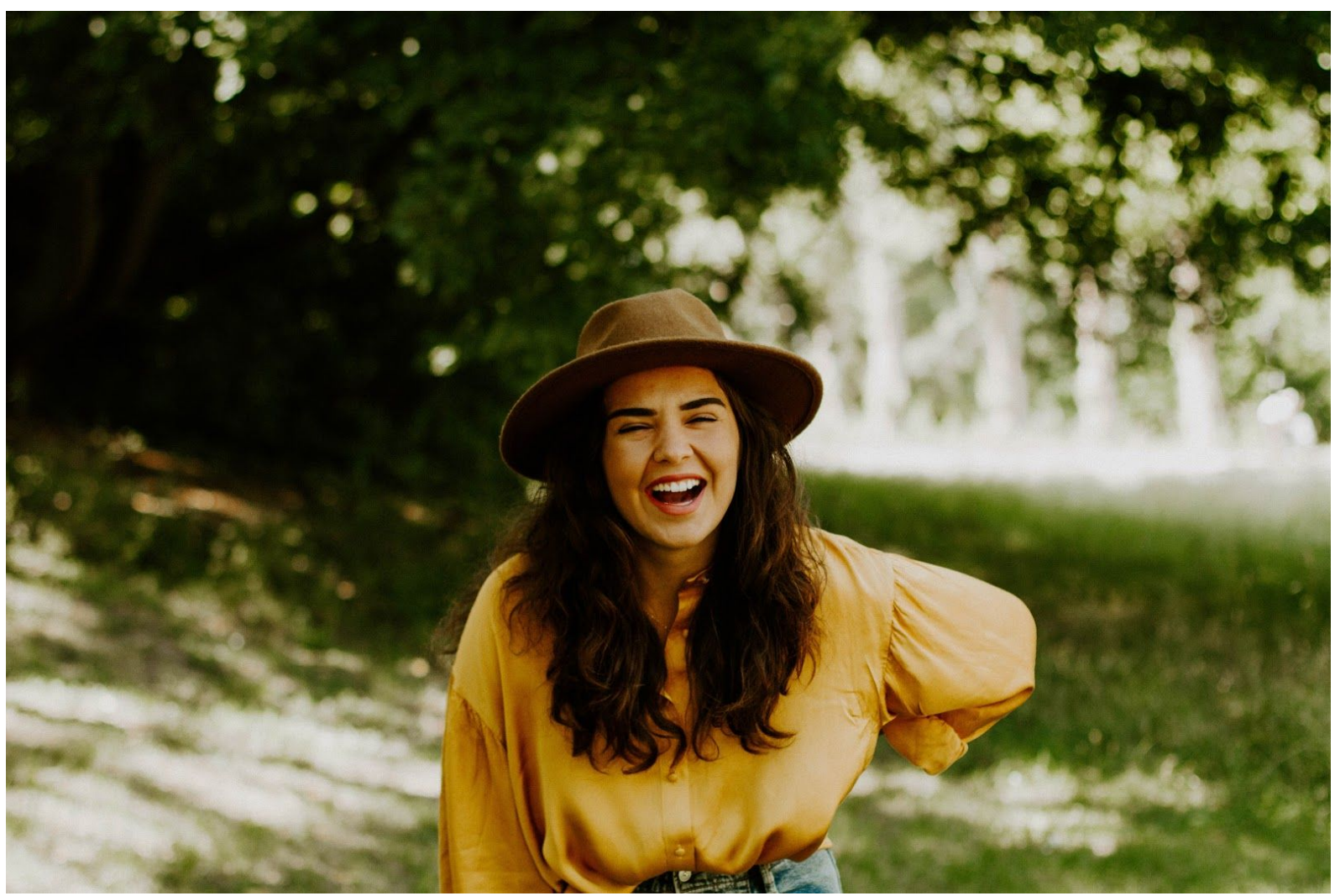

I'm Johanna, a Mexican-American portrait photographer, sometimes-writer, ethnology student, and the heart behind of The Together Project currently calling Freiburg, Germany home!

I'm passionate about sharing the kindness, light, and connection that humans have shown me across the globe- which is ultimately the inspiration behind The Together Project!

The Together Project is a series of photo essays inspiring us to see humankind in a different light while simultaneously honoring our differences while highlighting that we are so much more alike than we think we are. The Together Project is here to inspire you to have meaningful conversations, connect with others, to live life curiously, and to believe in one another. The world is NOT a scary place- rather, it's a place to be excited to explore. But what is the world without its people?

My favorite thing about adventure has always, always been the people I get to meet, although when I tell this to others they get a bit apprehensive. Although our outward worlds are different from one another, our inner worlds are consumed ultimately by one thing- a collective need for "togetherness." People are magic, I tell you- and I can't wait to start sharing these photo essays with you and hope they inspire you to see others with more love.

If you'd like to see more of my work, feel welcome to visit my website at http://www.johannapatton.com 